\title{
Discussion on the Application of "WeChat Public Platform" in the Fine Management of Universities
}

\author{
Min Wei \\ Library, Jilin Agricultural University, Changchun, 130118 \\ 434975141@qq.com
} Keywords: WeChat Public Platform, College Student Management Work, Fine Management,
Application

\begin{abstract}
In the modern times, the network media has developed rapidly, and the new media has been widely used in the management of all walks of life. With the continuous expansion of the scale of colleges and students, and the surge in the number of students, the fine management of colleges and universities has become an inevitable. At the same time, because of its openness, equality, interaction and data statistics and other functions, WeChat public platform has been widely used in the fine management of the University.
\end{abstract}

\section{Introduction}

The new network media Tencent WeChat business development has been quietly entered our life. When we started to pay attention to it, it has played an important role in people's life and study. WeChat public platform also belongs to a new media. The so-called new media is different from traditional media, newspapers, books and other forms, but with the help of information technology, mobile Internet technology through the Internet, wired and wireless communication network, the mobile phone, computer and other terminal equipment to the customer to exchange information and interactive entertainment new media.

In today's society, our country has experienced a rapid development process, is slowly entering a major turning point in society. Economic, cultural system reform, to a certain extent, it also promotes the economic and cultural interests and the diversification of the pattern of production. In the past few years, in order to strengthen the popularization of higher education in our country, our country has carried out a comprehensive enrollment plan. The surge in the number of college students and the University's own educational resources are not in sync with the sharp decline in the quality of teaching. In order to solve these problems, the management of college students becomes particularly important, and the concept of fine management in Colleges and universities is also rapidly put on the agenda. The three important duties of higher education are to cultivate high level talents for the country, to utilize the resources of universities to carry out scientific and social research, and to serve the society. Among them, the training of talent is the most important, the students can be said to be the core of the work of College management. How to achieve effective management and fine management of college students work is a problem that managers should explore. The various advantages of the new media, especially the emergence of WeChat's public platform, can be said to be born. This article mainly elaborated the WeChat public platform has the characteristic and the insufficiency as well as in the university fine management aspect the application situation and the exploration.

\section{Functions and Features of WeChat Public Platform}

Acquaintance Network, Small Diffusion, High Effective Communication. According to the latest WeChat official website user data statistics, its registered users in January 15, 2013 exceeded 300 million. For a mobile social software can be accepted by the public in a short time, one of the main reasons is that its users based on the existing Tencent users. At the same time, WeChat also can achieve cross platform friends to add, WeChat users can access the phone address book to add friends and family has opened WeChat business. WeChat is different from other similar social 
networking platform is characterized by the establishment of the circle of friends are already know the people; the establishment of the network is a network of acquaintances. The internal communication is a minority communication acquaintance based on network, the trust and the arrival rate is beyond the reach of the traditional media. So the platform can get more real group network, the school to create their own WeChat public number, can achieve the progress of the work of college students work fine management.

The Operation Is Convenient, and can Provide Information and Services at Any Time and Place. Relative to the PC, the mobile phone is a tool that the user will carry on the body at any time. With the advantage of mobile terminal, WeChat's natural social, location and other advantages will bring great convenience to the fine management of colleges and universities. At the same time compared to other APP software, because it does not need to download and install, with this more convenient. WeChat public platform is a powerful way to fine management in Colleges and universities. WeChat's public platform for the spread of one to many of the spread, the news directly to the phone, so the rate and the rate of being viewed is almost $100 \%$. There are a number of individuals or groups of public numbers because of their high quality push content and has a large number of fans groups. Due to the high degree of recognition of the students of the school WeChat public, is not easy to cause their resistance, plus a high rate of arrival and watch, can be a very good student management work to achieve the desired results.

Information Spread Fast, Interactive. WeChat as social software, its high spread speed and convenience of interactivity is different from the advantages of other network media. In particular, the WeChat public platform, student users can communicate with other friends as well as the fine management of the public to communicate with the university public number. Colleges and universities through the WeChat public numbers can be immediately sent to the student management information, rapid updates. At the same time can also be through the WeChat circle of friends' feature, through reprint, forwarding and "@”, function to the university management information release. And with the continuous progress of the network platform, WeChat public information platform will be more abundant. Management work of college students can also use the WeChat public platform to provide students with some of their life, learning can help the students in Colleges and universities, among which can better feelings, make more profound humanistic care in Colleges and universities.

\section{Problems in the Management of Traditional students in Colleges and Universities}

College student management is one of the main works of colleges and universities, and it is the basic guarantee and precondition for the realization of the three major social functions. In recent years, with the expansion of the scale of the country and the surge in the number of students in Colleges and universities, the students themselves and more efficient management and more personality and common problems. Therefore, the traditional college student management work has highlighted many new problems and challenges.

The Old and Mode of the Management Concept of College Students' Management. Traditional college student management work is to rely on the instructor and class student cadres as the main management of the development, a lot of people are used to manage the model. This model is conducive to the interactive communication between teachers and students, is not conducive to the large group model, the continuous expansion of the scale of colleges and universities, the number of students continue to surge. Old traditional management mode and concept not only increase the workload and the existence of a lot of blind management, but also cannot meet the needs of the current management needs, the need to change the old.

The Management of Students in Colleges and Universities Are Various and the Work Efficiency Is Low. Management work of college students who work safety and stability, the students entered the classroom and dormitory, inform the related units and things to handle business, management class, and some students talk and guide the graduates' job etc. Students work is also the complexity of the students encountered anything will be the first to get in touch with the school guidance teachers. This is bound to increase the difficulty of the work of college students work, and 
thus further affect their work efficiency.

College Students' Self-Binding Force Is Difficult to Increase the Difficulty of Management. The management of College Students under the old pattern, because of some limitations, subjective initiative make students play difficult to cast out, plus the management platform and backward management mode, let the students work in Colleges and universities managers in a very passive position. Even with the instructor and class cadre management, arrange and follow the prescribed order execution is passive position. Therefore, without the self-constraint management of college students, the work of the students in Colleges and universities is difficult to overcome the drawbacks brought by the defects of the system, even if the work is hard.

College Students' Sense of Freedom and Serious Personality of Students Themselves. University student management work of the object, the current is a strong personality after 90 groups. Because most of this generation is the only child, so they tend to form a relatively strong sense of freedom, and obedience to the concept of management will become very weak. The old management mode is "people rule people" thought; it is difficult to accept this group of 90 door handle, once not safe will cause their resentment. And this group of 90 students on new things, the new media is particularly keen. College students work management using WeChat platform is easier for students to accept, but also conform to the trend of the times.

\section{Application of WeChat Public Platform in the Fine Management of Universities}

WeChat public platform, breaking the original relationship between teachers and students, but also can be said to be an innovative revolution".

Promote the Management of College Students to Create a New Model. The college students' love for the new media and WeChat public platform, and according to the exact requirements of some management students in life, with innovation, create college students usually student life management of public platform. Then integrates some daily information notice, the key information retrieval, and the common problems of intelligent real-time recovery, platform culture and network interaction, innovation and other functions. More specific, frontier in the new period are some of the highlights for the students' management work, make more meticulous management of college students work, improve work efficiency while also opens up the path of innovation of new media management platform.

The Development of College Students in the Fine Management of the Enthusiasm and Initiative. Compared with the traditional management mode of "people rule people", the new generation of 90 college students prefers to be in the management mode of their own initiative. College students can through the WeChat public platform, the release of their learning plans and daily life of the trip; you can also find the relevant rules and regulations of the university students and training arrangements. Can also be used to study the fine management of the work of the public platform of the University of the work process, the previous notice, etc. Finally, WeChat public platform can also according to the requirements of students, students actively carry out collective activities of rich and colorful network, to increase the students' collective and students play in high in the management of the spirit of the masters.

Promote Teacher-Student Relationship and Develop a New Platform for Efficient and Meticulous Management Work. Like other social media software, WeChat's public platform is also equipped with a number of chat and interactive features. The teacher can have a human activity on many people and one to one-person online talk and some other management work with WeChat public platform and college students. Students can also use the WeChat platform to guide the teacher's teaching and management of the work of evaluation and advice. Fine work of the college students' management and guidance teachers can enjoy WeChat public platform administrator privileges, can undertake to the student classification, hierarchical division, in order to develop targeted counseling and training plan. In addition, WeChat public platform in the process of implementation, the University guidance teachers should also pay attention to the protection of students' privacy. 


\section{Conclusions}

The development and utilization of WeChat public platform provides an innovative way for the fine management of the work of college students. The number of mobile phone software using WeChat's current college students mostly, which are in the use of WeChat platform for public management has laid a good foundation, a good opportunity is the use of new media to carry out management work. The author believes that the university can be very good for students to work fine management, must pay attention to the application and development of new ideas for the management of the new WeChat platform.

\section{References}

[1] Li Yan, Zeng Weilun, He Haitao. A new carrier of Ideological and political education of university students under the new media environment [J]. Journal of Chongqing University of Posts and Telecommunications (Social Science Edition), 2010, (9): 21-26.

[2] Ma Xiaojie. Service Management: lead the College Student Affairs International Symposium (ISSA 2005) [M]. Wuhan: Huazhong University of Science and Technology press, 2008

[3] Zou Xiangrong, Wang Aiqing, Sun Zhisheng, Peng Yu. Integration of Capital Normal University student works platform planning and design [J]. China education information, 2010, (23).

[4] Sa Chengxian. Efforts to create a set of education, management services in one student work platform [J]. Journal of Shaanxi Normal University (Philosophy and Social Science Edition), 2003, (S1).

[5] Qi Hao. A discussion on the Countermeasures of strengthening the construction of College Students' work platform -- a case study of a university in southern China [J]. Journal of Changchun University of Science and Technology, 2012, (5).

[6] CPC Central Committee of the State Council on Further Strengthening and improving the ideological and political education of college students [Z]. General Office of the CPC Central Committee, 2004

[7] Xiao Xuebin, Zhu Li. The impact of new media on College Students' Ideological and political education and Its Countermeasures [J]. Research on Ideological Education, 2009, (7): 54-56.

[8] Xu Zhenciang. The opportunities and challenges of new media _ ideological and political education of College Students [J]. Research on Ideological Education, 2007 (6): 64

[9] Wang Jin. Research on the effectiveness of the ideological and political education in the network of colleges and universities [M]. Nanjing: Nanjing Normal University press, 2004

[10] Introduction to the basic principles of Marxism Marx. Introduction to the basic principles of Marx [M]. higher education publishing house, 2008

[11]Propaganda Department of the CPC Central Committee Propaganda Department of education, Ministry of education, social science research and the ideological and political work in our department, Central Committee of the Communist Youth League school group.

[12]Zeng Guangxia, Wu Jiang. The opportunity and challenge of Ideological and political work in Colleges and universities [J]. East China Journal of Kasetsart University (Social Science Edition), 2002, (1): 98-99. 